\title{
Relevance of Capital Structure in Developing Countries: A Special
}

\section{Focus on India}

\author{
Sarada Dakua*
}

\begin{abstract}
India being the top exporter of iron ores has the potential to be counted as one of the top exporters of steel if the steel companies follow optimal capital structure. On the contrary, there has been a history of financial issues such over/under-leverage in this sector for which the companies have not been able to perform as per their potential. Since neither India is a developed country nor its steel companies are financially self-sufficient, they are bound to depend on the external capital resulting the decision to be taken on the leverage ratio as even more crucial. Thus it is trivial to investigate the leverage ratio in order to decide the optimal capital structure. However, the first and foremost step is to test if the capital structure of Indian steel industry is relevant to Indian steel companies' values, which is the objective of this study. It is found that capital structure has little significance to Indian steel companies' firm values.
\end{abstract}

Keywords: Capital structure, Indian steel industry, relevance, finance.

\section{Introduction}

Foreign direct investment (FDI) is necessary for any government to economically and sustain the growth. However, this depends on the government and its policy. Until 1990s, Government of India had almost closed its door for FDIs. The Indian government changed its policy in 1991 and allowed FDI reforming the industries. Major sectors like construction, housing, transportation, power generation then started to grow exponentially, thus the demand for steel increased proportionately. Since the Indian steel industry could not meet the demand, most of the demand was met by steel imports (Dutta \& Mukherjee, 2010). Since then the Government of India (GOI) has significantly reformed its steel industry and now India is the second largest producer of crude steel (Ministry of steel 2017). However, India could be the top exporter if proper capital structure is designed and implemented. It may be speculated that the iron sector has appropriate capital structure and therefore probably India is the top exporter of iron ores (Handoo \& Sharma, 2014). Financially, high demand or high scale of steel industry operations do not mean that the industries will be profit making until unless there is no issue of financial over- or under-leverage. This is noticed in 2001, despite fairly strong operations and high prices of steel, most of the Indian steel companies failed to report profits and even some were not able to meet the debt obligations. Therefore, Indian Government suggested (Ministry of steel 2017) that it would encourage its steel industry to reduce capital costs and develop capital structure to minimize the debt and service equity. This makes sense since GOI has

*School of Business, University of Leicester, United Kingdom. Email: sdakuale@gmail.com 
allowed FDI in steel sector and the Indian companies have to compete with the foreign players in steel industry especially from China. In other words, an optimum leverage ratio policy may be required.

The capital theory concept started by Modigliani and Miller in 1958 (Modigliani \& Miller, 1958) and 1963 (Modigliani \& Miller, 1963). The first irrelevance theory in 1958 stirred the world and the researchers were motivated to pour modified concepts on capital structure. As a result, the tradeoff theory (Myers, 1984; Kraus \& Litzenberger, 1973) showed up followed by pecking order theory (Myers \& Majluf, 1984), and then market timing theory (Allini, Rakha, McMillan, \& Caldarelli, 2018) and so on. In order to sustain any firm, huge capital is crucial; but the big question remains, "what will be the source of this capital?". Pecking order theory does assist in this; it says the retained earnings should be chosen first. If it is not sufficient or not available, shares can be floated in the market as equity and lastly, external loan should be preferred. However, at present, it is not viable to either depend solely on internal or external fund. There has to be a balance between debt and equity. As per the pecking order theory, the firms do not have any optimal leverage ratio whereas the trade-off theory does believe that the firms do have optimal leverage ratio. Kraus and Litzebnerger propose trade-off theory in 1973; according to this theory, the determination of the optimal leverage ratio is possible by making a trade-off between the cost of debt and the benefits. Companies can alter debt with equity and vice versa in order to maximize the company value.

Till the date there is no consensus among the researchers to agree on a particular theory and therefore, the theories probably should be analyzed with respect to a certain type of industry, country, location, infrastructure, etc. So the determination of determinants deciding the capital structure becomes pivotal along with optimal capital structure. Again there have been studies that find the capital structure in certain countries is irrelevant to their firm values.

\section{Literature Survey}

There are theories that describe the relationship of capital structure with financial decisions. Modigliani and Miller (Modigliani \& Miller, 1958) in their first proposition suggest that the capital structure is irrelevant to companies' financial decisions because of some simplifying assumptions such as no taxes, no transaction costs, and no information symmetry. As per this theory, the risk and return of the company's real assets decide the total market value of all financial assets (Byström, 2017).

Modigliani and Miller propounds that the gearing does not affect the weighted average cost of capital (WACC) of a company because in the balance of two countervailing forces. Their argument was based on the supposition that the value of a geared company is equal to that of its un- geared counterpart because of arbitrage. According to the leverage or gearing effect, the corporate value increases with debt, however, the modification of risk was not considered with the firm value. The debt also increases the risk simultaneously sometimes leading to bankruptcy. Therefore, the supposition was incorrect; it did not consider the risks (such as taxes and others) associated with the debt. Modigliani 
and Miller again modified (Modigliani \& Miller, 1963) this proposition and incorporated the effect of corporate and personal taxes that indicated the existence of optimal capital structure; here they too considered the market imperfections.

There are certain benefits of debt financing such as tax shield; they report that the firm value will be increased by debt financing by reducing tax liability. However, too much debt financing brings agency cost of the debt due to information asymmetry (Jensen \& Meckling, 1976). There are also concerns such as risk of bankruptcy and financial distress that limit the scope for debt financing. In order to mitigate this issue, Myers develop the concept of optimal debt level through trade-off theory. The debt is the balance between the benefits of tax shield and financial distress; if the debt exceeds the limit, the cost of debt will decrease the firm value. Thus it says that the company value is positively related to its debt; profitable companies use more debt to avoid paying huge taxes (they get a tax shield). In an all equity company, the shareholders own the value of the company and a portion goes to taxes as a cost; whereas shareholders, debt holders and tax recipients own the value of a levered company. The value is maximized when payment for taxes is low. On the other hand, pecking order theory provides ways for the managers on how to prioritize the sources of finance. It says that internal finance must be preferred in any scenario. In case, external finance is still desired, the following resources must be followed: 1) debt, 2) hybrid securities, 3) equity. Market timing theory (Allini et al., 2018) is quite contrast to both trade-off and pecking order theory; it says that a company having lower level of leverage should raise capital when its market variation is high, as measured by marketto-book ratio. At the same time, a company with higher level of leverage should raise capital when its market variation is less.

Figure 1

(a) Capital structure and financial leverage are two key factors of profits made by the steel companies.

(b) Survey substantiating the claim that profits are made due to the capital structure (especially) is done in USA and Europe; extensive survey is yet to be conducted on Indian steel industry.

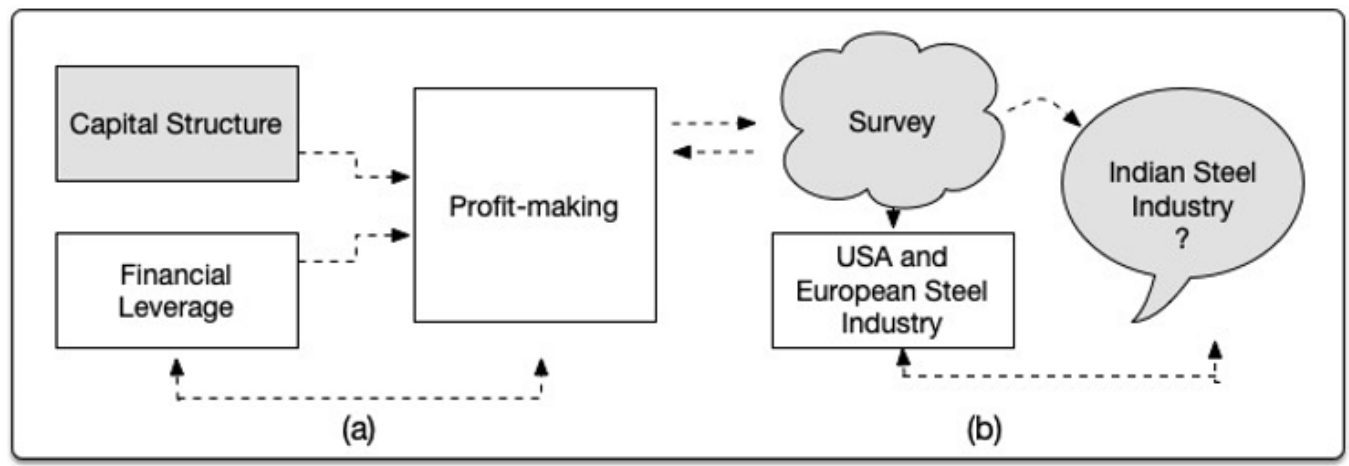

The tradeoff theory says that the cost of debt sometimes offset the benefits of debt. That means there should be an optimal capital structure where both cost and benefit are balanced (Stulz, 1990). Diamond (1989) reports that as companies get older they prefer to 
invest on less risky projects. Agency models report that leverage is negatively correlated with interest coverage, growth opportunities and possibility of reorganization. Pecking order theory (Myers, 1984) arises due to information asymmetry and it states that companies usually prioritize their source of funding by the following order: internal fundsdebt-equity. However, Constantinides and Grundy Constantinides and Grundy (1989) argue that if a company has wide range of financial choices, the results by Myers et al. are nullified on some cases.

\section{Rationale to Study Indian Steel Industry}

Usually, companies look for raising capital in order to gain higher leverage ratios, especially the bigger companies; this happens in Europe and United States of America (Strebulaev \& Kurshev, 2006). The investors usually get motivated to invest in such companies because they believe that big companies 1) have proper capital structure, 2) have the potential to divert the unused fund, 3) usually do not easily bankrupt, and 4) are more transparent since the scrutiny level is very high and quite reliable. Besides USA and Europe, Africa is a big continent (at least size-wise) that can't be ignored. Gwatidzo and Ojah (2014) have found that the capital structure in Africa depends on several variable such as corporate tax, profitability, size, and firm age. Pecking order theory is followed by most of the companies in Africa.

The impact of leverage on firms' performance needs to be studied. There have been many studies (Rajan \& Zingales, 1995; Abor, 2005), where debt is found to have negative effect on the firm's performance (Simerly \& Li, 2000). It must also be mentioned that short-term debt sometimes could have positive impact on the performance. Similarly, its negative impact could be realized in the case of long-term debt (Appiadjei, 2014). The leverage is found to have positive effect on the company's performance. The leverage is both positively and negatively impacted by the variables too; this is reported to positively correlate with non-debt tax shields, fixed assets, size of company, and growth opportunities, whereas it correlates negatively with profitability. The profit is related to the leverage; (Fan, Titman, \& Twite, 2012) find that profitable companies should have lower leverage; the higher is the rate of economic growth, the lesser should be the leverage.

Although the researches have been trying to establish a consensus on a single theory that fits for all, unfortunately, the findings are still inconclusive. Importantly, most of the studies that have been conducted so far are based on US and European markets (shown in Figure 1), therefore, plenty of space for research is there to focus on emerging economies such as India.

\section{Link to Research Question}

In context with India, the growing reforms in the capital market have resulted the wave of privatization, issuance of debts, issuance of equities etc., which have transformed the companies into more with debt prominent capital structures. A few attempts report that the capital structure is complex in Indian context. Chakraborty (2010) present two meth- 
ods to estimate and analyze the determinants of Indian firms using a panel of 1169 nonfinancial firms listed in either the Bombay Stock Exchange. Both pecking order theory and trade-off theory seem to explain the Indian firms' decisions.

There exists a low volume of papers and reports that really reflect the lack of interest by the top management(s) to seriously consider the importance of capital structure of the steel industry in India. Even comprehensive information of the relevant data does not exist in most of the public databases. One reason could be the absence of foreign direct investment in this sector earlier because probably the previous governments did not want to expose this sector to completion since it is one of the backbones of the economy. After the present Government made this sector open to foreign players, suddenly the top managements wish to be proactive and adapt corrective measures and do some reforms and re-structuring in order to compete with the foreign players. Hence the capital structure now needs to be properly studied before an optimum ratio is finalized. Also it could be well possible that capital structure is irrelevant in Indian context, that's why capital structure has been ignored all these years. In order to know these facts, an empirical study is needed and in this respect and that is sole objective of this work.

\section{Relevance of Capital Structure}

The ratio of debt over total capital or assets can be considered as the leverage that could well be used as a proxy to study the capital structure determinants. The relevance of capital structure to company's value should be first determined before the determinants affecting the capital structure are identified. This describes the business environment in a country; furthermore, it indicates the tax policies, governance controlling the business in the country, etc. India being a diverse country with respect to religion, language, culture, institutional characteristics, etc. further demands to test the relevancy (Vo, 2017).

Ibrahimo and Barros (2009) present a study on the asymmetric information effects of financial equilibrium and firms' capital structure on firms' value or performance and they find that it is relevant and it matters. They find that the amount outside the equity results significant difference to the quantity of aggregate investment in equilibrium. Martellini, Milhau, and Tarelli (2018) present a general framework for a corporation to take a decision on optimal capital structure that is under tremendous pressure such that it could be bankrupt. They present joint quantitative analysis of capital structure decisions in a continuoustime setting optimizing the debt structure that leads to a direct impact on the capital structure decisions in the presence of interest-rate and inflation risks. They find that by jointly optimizing the debt and capital structure a significant increase in firm value can be obtained. They also find that by issuing inflation-linked bonds, the corporations could benefit. They use data from Standard \& Poor's Compustat database; they consider certain firms in their research that have information on: variables DATA9 (Long-term debt Total) and DATA148 (Long-term debt tied to prime).

Ata et al. study the impact of capital structure on financial performance in Indian steel industry and they find a negative relationship; they obtain the data for their research from Bombay Stock Exchange and National Stock Exchange of just 13 companies of the duration 2007-2012. Bandyopadhyay and Barua (2016) use a two-step dynamic panel 
generalized method of moments (GMM) to test the relationship between capital structure and firm's performance; they find that corporate financing decisions are influenced by the macro economic cycle significantly and thus is the performance. They find the relevance of asymmetric information, agency cost, and trade-off theory in most of the Indian capital structure decisions. They use panel data of 1594 Indian corporate firms of the interval 1998 to 2011. At the same time, Sharma (2017) finds that the Indian firms generally do not maintain a stable level of leverage over long durations, where he considers the corporate firms for the period 1988-2015. Kavous presents a report (Ardalan, 2017) on the rationale behind the Modigliani and Miller's theory and their assumptions; he finds that by more appropriate assumptions, the capital structure becomes more relevant. At the end, he raises also concern about the scientific nature of the mainstream academic finance since mathematical models change with the assumptions.

From the literature, it is found that the relevance largely depends the assumptions made during the analysis. In Indian context, the although the assumptions made by MM theory don't hold good, however, they do not violate too due to the absence of clear cut tax policies and others. The government has recently, started to impose strict policies and therefore, it needs to be checked from the analysis if capital structure is irrelevant to firm values.

\section{Data and Methods}

\section{Data}

Most of the previous studies have reported until 2010; therefore, it is decided to study the performance of Indian steel industry from 2010 to 2017. The capital structure of this duration will be analyzed and the significant determinants that affect the capital structure will be identified. The data has been obtained from the Centre for Monitoring Indian Economy (CMIE) Prowess database (CRISIL 2018).

Although there are more than 300 steel companies in India, the final list of companies is less than 50 as per the criteria taken for the investigation as follows. The sample steel companies are selected for this research under certain criteria: in 2010, the firm should be in top 50 companies by sales during the last financial year, the companies must exit till the financial year 2017, and there should not be any negative value for total assets during the study period. In other words, it is intended to include mostly profitable companies. In this way, it is tried to finalize 50 firms for the period 2010-2017.

Again these 50 companies are filtered and the companies having missing desired information are excluded. In this way, the sample size is restricted to 42 . The steel companies included in the study are both listed and unlisted steel companies in India. Here it is aimed to determine the major determinants of capital structure and study how they affect the capital structure. The samples obtained are both time series and cross sectional data also called panel data. 


\section{Methods}

Three types of methods used to analyze the panel data are: 1) pooled regression, 2) fixed effects model, and 3) Random effects model.

These methods will be used according to the hypotheses considered in the study. All the models will be carried with the help of Statistical Package for the Social Sciences (SPSS) package.

\section{Analysis and Results}

\section{Relevance of Capital Structure}

Without doubt, the capital structure models that follow time varying firm effects perform better to explain the variations in leverage. Therefore, it is not sure if the capital structure has any impact on Indian steel industry, which will be examined in this study. The data will be examined in order to estimate if the capital structure is irrelevant to the firm value. Thus it will be investigated if Modigliani \& Miller's theory holds good in Indian steel industry context.

The hypothesis is stated as follows:

H0: $\mu \geq 0: 05$ (debt-equity ratio is not correlated to earning per share)

$\mathrm{H} 1: \mu \geq 0: 05$ (debt-equity ratio is correlated to earning per share)

Panel data is proffered to provide more observations and larger sample status. The data may be analyzed using the central limit theorem (Wang, 2008) making the analysis more efficient.

\section{Descriptive Statistics}

Descriptive data format is easy to analyze and interpret; therefore, this format is preferred in this work too. The descriptive statistics covered in this study are:

\section{Central Tendency Measures}

$$
\text { Samplemean }=\text { sum of all observations/no. of observations }
$$

- Median: it is middle of the data observations

\section{Measures of Dispersion}

Minimum, maximum, and the range: minimum, maximum, and the range are the smallest observation, biggest observation, and the difference between the smallest and the biggest observations. 


\section{Measures of Variability}

- Variance: it is the average of the squared deviations from the mean.

- Standard deviation: it is the square root of the variance.

\section{Regression Analysis}

Regression analysis is a statistical tool to quantitatively investigate the relationships between variables; for this also a panel data analysis is conducted. Panel data regression in particular helps in adjusting or counting the missing variables and reducing the possibility of multicollinearity that is very much common in time series data. The data used in panel data regression analysis has been collected from different steel companies in India over a period of 7 years.

The Frank \& Goyal model is followed; this study model is represented as:

$$
Y_{i t}=\alpha+X_{i t}^{\prime} \beta+\epsilon_{i t}
$$

Where $\mathrm{Y}, \mathrm{X}, \beta, \epsilon, \mathrm{i}$, and $\mathrm{t}$ represent dependent variable, explanatory variable (as will be discussed in context later), explanatory variables' coefficients, error term, individual steel company, and time subscript, respectively. The firm's performance will be proxied by earnings per share (EPS); here it is aimed to estimate if EPS has significant relationship with debt to equity ratio, corporate tax-shield ratio, and asset tangibility (AT). Therefore,

$X=$ debt to equity ratio, corporate tax-shield ratio, and asset tangibility.

$\mathrm{Y}=$ firm's performance in form of EPS.

$\epsilon_{i t}=$ it can be further decomposed into company specific effects and error term as:

$$
\epsilon_{i t}=d_{i}+\xi_{i t}
$$

Where $d_{i}$ and $\xi_{i t}$ are the specific effects (fixed parameter for every steel company) and company specific error term (independent and identically distributed), respectively. Therefore, equation 1 becomes

$$
Y_{i t}=\alpha+X_{i t}^{\prime} \beta+d_{i}+\xi_{i t}
$$

This model is also called fixed effect model or least square dummy variable model (Bruno 2005). Here number of dummies introduced equals to number of companies minus one that means 41 dummies are to be included. Since three independent variables, i.e. debt to equity ratio (DE), tax shield (TS), and asset tangibility (AT) are selected, the equation 3 can be written as:

$$
E P S_{i t}=\alpha+\beta_{1}\left(\frac{D}{E}\right)_{i t}+\beta_{2}(T S)_{i t}+\beta_{3}(A T)_{i t}+d_{i}+\epsilon_{i t}
$$

Where $\left(\frac{D}{E}\right)_{i t}$-earnings per share of a steel company $\mathrm{i}$ in time $\mathrm{t}$. $(T S)_{i t}$-Tax shield is the tax to net income ratio of a steel company $i$ in time $t$. 
$(A T)_{i t^{-}}$-Asset tangibility is the ratio of fixed assets to total assets of a steel company $\mathrm{i}$ in time $\mathrm{t}$.

The debt to equity ratio is the proxy for the capital structure can further be decomposed as:

$$
\left(\frac{D}{E}\right)_{i t}=\delta+\gamma_{1}(\text { Size })_{i t}+\gamma_{2}(\text { Profit })_{i t}+\gamma_{3}(T S)_{i t}+\gamma_{4}(A T)_{i t}+\xi_{i t}
$$

Where $\left(\frac{D}{E}\right)_{i t}$-the market cap of steel company $\mathrm{i}$ in time $\mathrm{t}$.

$(\text { Profit })_{i t}$-Return on asset of a steel company $\mathrm{i}$ in time $\mathrm{t}$.

\section{Descriptive Statistics}

Central tendency theory is crucial in descriptive statistics; the idea behind the Central tendency theory is to identify the one that best defines summarizes the entire dataset or set of measurements. In other words, this number is center to the entire data set or set of measurement. Several measures of central tendency and dispersion were computed during regression analysis to express the underlying distribution of each variable. These measures are provided in Table 1.

\begin{tabular}{lcccccc}
$\begin{array}{l}\text { Table } 1 \\
\text { Descriptive statistics }\end{array}$ & & & & & & \\
\hline $\begin{array}{l}\text { Statistical } \\
\text { measures }\end{array}$ & AT & Debt to equity & EPS & MCAP & ROA & TS \\
\hline Mean & 47.54 & 63.18 & 3.75 & 8.98 & 10.41 & 37.26 \\
Median & 38.25 & 41.99 & 1.88 & 3.01 & 8.35 & 46.13 \\
Maximum & 631.9 & 595.72 & 54.43 & 75.85 & 511.23 & 275.19 \\
Minimum & 0.00 & 0.00 & -8.17 & 0 & -44.55 & -3258.19 \\
Standard Deviation & 37.42 & 86.04 & 5.41 & 14.96 & 20.47 & 138.88 \\
\hline
\end{tabular}

\section{Unit Root Test}

A variable is considered to be explosive when it has unit root and a variable can't be included in a model if it has unit root or non-stationarity (Levin, Lin, \& Chu, 2002). This is because financial series usually has underlying growth rate; if the non-stationarity is included in regression models, it may lead to spurious regression results. Therefore, the unit root test needs to be checked to make sure if the underlying variables are suitable for the regression analysis.

The unit root test for panel data can be structured as:

$$
\Delta y_{i t}=\rho_{i} y_{i, t-1}+\sum_{l=1}^{p_{i}} \varphi_{i, l} y_{i, t-l}+\alpha_{i} d_{i t}+\epsilon_{i t}
$$

Where $d_{i t}=$ deterministic components, $\rho_{i}<0$ means that $\mathrm{y}$ is stationary around. $\rho=0$ indicates that $\mathrm{y}$ has a unit root for all $\mathrm{i}$. In the hypothesis proposed by Levin et al. (2002), $\rho_{i}$ are identical and negative. Since data from different companies need to be 
combined into a final regression, $\rho_{i}$ is set fixed for all $i$. The results of the unit root test are shown in Table 2.

\begin{tabular}{lccc}
$\begin{array}{l}\text { Table } 2 \\
\text { Unit root test }\end{array}$ & & & \\
\hline Method & Statistics & Probability & Cross sections \\
\hline AT & -324.315 & 0.000 & 42 \\
Debt to equity Ratio & -4.65143 & 0.000 & 42 \\
EPS & -3.29689 & 0.000 & 42 \\
TS & -214.108 & 0.000 & 42 \\
ROA & -16.1926 & 0.000 & 42 \\
MCAP & -11.6415 & 0.000 & 42 \\
\hline
\end{tabular}

The results show that all the variables are stationary; therefore, they can be included in the regression model. The Fisher test probabilities are computed using asymptotic $\chi^{2}$ distribution

\section{Regression Results of Capital Structure Irrelevance}

Since it is aimed to use the cross section for this study and it is exhaustive nature-wise, Fixed effects model has been chosen, furthermore, it can control the unobserved heterogeneity between the steel companies and it is constant over time. Eviews software (EVIEWS 2018) has been used since it is a powerful statistical tool through object-oriented interface. This is known for its use in econometric analyses such as cross-section and panel data analysis.

The results of fixed effect model (FEM) regression are shown in Table 3 and 4; panel least squares method is used with cross sections 42 and a total panel of 294 .

Table 3
\begin{tabular}{lcccc}
\multicolumn{5}{l}{ FEM regression where firm value is the dependent variable } \\
\hline Variable & Coefficient & Stand. Err. & t-stat. & Probability \\
\hline Constant & 4.451445 & 0.387082 & 11.500005 & 0.000 \\
(common intercept) & 0.003123 & 0.002981 & -1.047635 & 0.2957 \\
Debt to equity ratio & -0.0015 & 0.001095 & 1.369863 & 0.1718 \\
EPS & -0.011014 & 0.006336 & -1.73832 & 0.0832 \\
Asset tangibility & & & & \\
\hline
\end{tabular}

The results show that none of the explanatory variables are quite significant at $5 \%$ level except the AT, which is significant at $10 \%$ level. The debts to equity ratios are also insignificant in this model; that means they do not have any explanatory power on firm value (EPS). The R2 value stands at $60 \%$ indicating that the model can describe $60 \%$ of the variance in the firm value. F-statistic supports its significance at $5 \%$ level. 
Table 4

FEM regression where firm value is the dependent variable

\begin{tabular}{lclc}
\hline Measure & Value & Measure & Value \\
\hline R2 & 0.595383 & Adjusted R2 & 0.512079 \\
Std. error of regression & 3.677578 & Sum of squared of residuals & 7871.354 \\
Log likelihood & -1732.85 & F-statistics & 12.7827 \\
Prob. (F-statistic) & 0.000 & Mean dependent var & 3.86697 \\
Standard deviation & 5.475 .44 & Durbin-Watson stat var & 1.078594 \\
Akaike info criterion & 5.541108 & Schwarz criterion & 6.009468 \\
\hline
\end{tabular}

\section{Discussion}

From the analysis on the relevancy of capital structure in Indian context, it is found that the debt to equity ratio has little explanatory power on the EPS or firm value. Since almost all the firms are traded on market, their market capitalization (firm's share price multiplied by number of shares) equals to the market value of the equity. Therefore, most of the firm values are well affected by the market effects. The R2 value stands at $60 \%$ indicating that the model can describe $60 \%$ of the variance in the firm value that is well supported by F-statistic at 5\% level.

\section{Conclusion}

When the MM theory is studied with regard to Indian steel industry, it is found that capital structure has little significance to Indian steel companies' firm values. It is believed that the large firms generally diversify their funds intelligently and therefore, the danger of bankruptcy is minimal. Therefore, the firm size is usually expected to be a significant factor, surprisingly its high significance was not found in this study. It is felt that: 1) the steel companies need to increase the production efficiency in order to increase the profitability, 2) the steel companies can decrease their cost in order to increase the profitability, 3 ) in order to attract more lenders, the business risk aspect can be reduced. Although the sample data used in this study represent the aggregate average of the Indian steel industry, it is believed that a there is still space to improve the accuracy of this study, because forty two steel companies out of more than 300 companies have been included. In future, we intend to expand the sample size and improve the accuracy for the readers' benefits and knowledge. 


\section{References}

Abor, J. (2005). The effect of capital structure on profitability: an empirical analysis of listed firms in ghana. The Journal of Risk Finance, 6(5), 438-445.

Allini, A., Rakha, S., McMillan, D. G., \& Caldarelli, A. (2018). Pecking order and market timing theory in emerging markets: The case of Egyptian firms. Research in International Business and Finance, 44, 297-308.

Appiadjei, E. A. (2014). Capital structure and firm performance: Evidence from ghana stock exchange. Research Journal of Finance and Accounting, 5(16), 37-43.

Ardalan, K. (2017). Capital structure theory: Reconsidered. Research in International Business and Finance, 39, 696-710.

Bandyopadhyay, A., \& Barua, N. M. (2016). Factors determining capital structure and corporate performance in India: Studying the business cycle effects. The Quarterly Review of Economics and Finance, 61, 160-172.

Byström, H. (2017). The currency composition of firms' balance sheets, asset value correlations, and capital requirements. Global Finance Journal, 34, 89-99.

Chakraborty, I. (2010). Capital structure in an emerging stock market: The case of India. Research in International Business and Finance, 24(3), 295-314.

Constantinides, G. M., \& Grundy, B. D. (1989). Optimal investment with stock repurchase and financing as signals. The Review of Financial Studies, 2(4), 445-465.

Diamond, D. W. (1989). Reputation acquisition in debt markets. Journal of Political Economy, 97(4), 828-862.

Dutta, M., \& Mukherjee, S. (2010). An outlook into energy consumption in large scale industries in India: The cases of steel, aluminium and cement. Energy Policy, 38(11), 7286-7298.

Fan, J. P., Titman, S., \& Twite, G. (2012). An international comparison of capital structure and debt maturity choices. Journal of Financial and quantitative Analysis, 47(1), 23-56.

Gwatidzo, T., \& Ojah, K. (2014). Firms' debt choice in africa: are institutional infrastructure and non-traditional determinants important? International Review of Financial Analysis, 31, 152-166.

Handoo, A., \& Sharma, K. (2014). A study on determinants of capital structure in India. IIMB Management Review, 26(3), 170-182.

Ibrahimo, M. V., \& Barros, C. P. (2009). Relevance or irrelevance of capital structure? Economic Modelling, 26(2), 473-479.

Jensen, M. C., \& Meckling, W. H. (1976). Theory of the firm: Managerial behavior, agency costs and ownership structure. Journal of Financial Economics, 3(4), 305-360.

Kraus, A., \& Litzenberger, R. H. (1973). A state-preference model of optimal financial leverage. The Journal of Finance, 28(4), 911-922.

Levin, A., Lin, C.-F., \& Chu, C.-S. J. (2002). Unit root tests in panel data: Asymptotic and finite-sample properties. Journal of Econometrics, 108(1), 1-24.

Martellini, L., Milhau, V., \& Tarelli, A. (2018). Capital structure decisions and the optimal design of corporate market debt programs. Journal of Corporate Finance, 49, 141-167.

Modigliani, F., \& Miller, M. H. (1958). The cost of capital, corporation finance and the theory of investment. The American Economic Review, 48(3), 261-297. 
Modigliani, F., \& Miller, M. H. (1963). Corporate income taxes and the cost of capital: A correction. The American Economic Review, 53(3), 433-443.

Myers, S. C. (1984). Capital structure puzzle. National Bureau of Economic Research Cambridge, Mass., USA.

Myers, S. C., \& Majluf, N. S. (1984). Corporate financing and investment decisions when firms have information that investors do not have. Journal of Financial Economics, 13(2), 187-221.

Rajan, R. G., \& Zingales, L. (1995). What do we know about capital structure? Some evidence from international data. The Journal of Finance, 50(5), 1421-1460.

Sharma, P. (2017). Long-term persistence in corporate capital structure: Evidence from India. Research in International Business and Finance, 42, 249-261.

Simerly, R. L., \& Li, M. (2000). Environmental dynamism, capital structure and performance: A theoretical integration and an empirical test. Strategic Management Journal, 21(1), 31-49.

Strebulaev, I. A., \& Kurshev, A. (2006). Firm size and capital structure. In EFA 2005 Moscow Meetings Paper.

Stulz, R. (1990). Managerial discretion and optimal financing policies. Journal of Financial Economics, 26(1), 3-27.

Vo, X. V. (2017). Determinants of capital structure in emerging markets: Evidence from Vietnam. Research in International Business and Finance, 40, 105-113.

Wang, P. (2008). Financial econometrics. Routledge. 